\title{
Propofol prevents delayed neuronal death following transient fore- brain ischemia in gerbils
}

Shigeki Yamaguchi MD,

Yukio Midorikawa MD,

Yasuhisa Okuda $M D$,

Toshimitsu Kitajima MD

Purpose: This study was conducted to ascertain whether propofol may protect against delayed neuronal death in the hippocampal CAI subfield in gerbils.

Methods: Thirty-five gerbils were randomly assigned to five groups: Group I, the control group, a sham operation treated with physiological saline solution (PSS); Group II, ischemia/reperfusion treated with PSS; Group III. ischemia/reperfusion treated with $50 \mathrm{mg} \cdot \mathrm{kg}^{-1}$ propofol; Group IV, ischemia/reperfusion treated with $100 \mathrm{mg} \cdot \mathrm{kg}^{-1}$ propofol; Group V, ischemia/reperfusion treated with $150 \mathrm{mg} \cdot \mathrm{kg}^{-1}$ propofol. Transient forebrain ischemia was induced by occluding the bilateral common carotid arteries for four minutes under $\mathrm{N}_{2} \mathrm{O} / \mathrm{O}_{2}$ /halothane anesthesia after administration of propofol or PSS. Five days later, histopathological changes in the hippocampal CAI subfield were examined using a light microscope and degenerative ratio of the pyramidal cells were measured according to the following formula: (number of degenerative pyramidal cells/total number of pyramidal cells per $1 \mathrm{~mm}$ of hippocampal CAI subfield) $\times 100$.

Results: In group II, the pyramidal cells were atrophic and pycnotic; vacuolation and structural disruption of the radial striated zone was observed. In the other four groups, these changes were not observed. The degenerative ratios of pyramidal cells were as follows; group I: $5.9 \pm 1.9 \%$, group II: $94.6 \pm 2.5 \%(P<0.01)$, group III: $10.7 \pm 1.7 \%$, group $\mathrm{V}: 9.7 \pm 1.8 \%$, group V: $9.2 \pm 1.9 \%$.

Conclusion: This study suggests that propofol may prevent delayed neuronal death in the hippocampal CAI subfield after cerebral ischemia/reperfusion in gerbils.

Objectif : La présente étude a été menée pour vérifier si le propofol peut protéger contre la mort neuronale retardée du sous-champ CAI hippocampique chez des gerbilles.

Méthode : Trente-cinq gerbilles ont été répartis au hasard en cinq groupes : le groupe I, térnoin, subit une opération fictive traitée avec une solution physiologique salée (SPS); les autres gerbilles subissent une ischémie/reperfusion traitée dans le groupe II avec une SPS; dans le groupe III, avec $50 \mathrm{mg} \cdot \mathrm{kg}^{-1}$ de propofol; dans le groupe IV, avec $100 \mathrm{mg} \cdot \mathrm{kg}^{-1}$ de propofol et dans le groupe $V$, avec $150 \mathrm{mg} \cdot \mathrm{kg}^{-1}$ de propofol. L'ischémie transitoire du cerveau antérieur a été induite par l'occlusion bilatérale des artères carotides communes pendant quatre minutes sous anesthésie au $\mathrm{N}_{2} \mathrm{O} / \mathrm{O}_{2}$, halothane après l'administration de propofol ou de SPS. Cinq jours plus tard, on a vérifié les changements histopathologiques survenus dans le sous-champ CAI hippocampique à l'aide d'un microscope optique et le taux de dégénérescence des cellules pyramidales a été mesuré comme suit : (nombre de cellules pyramidales dégénératives/nombre total de cellules pyramidales par mm de sous-champ CAl hippocampique) $\times$ 100.

Résultats : Dans le groupe II, on a noté des cellules pyramidales atrophiques et pycnotiques; on a aussi observé la vacuolisation et la rupture structurale de la zone radiale striée. Dans les quatre autres groupes, ces changements n'ont pas été notés. Les taux de cellules pyramidales dégénératives étaient pour le groupe I: $5,9 \pm 1,9, \%$, le groupe II : 94,6 $\pm 2,5 \%(P<0,01)$, le groupe III : $10,7 \pm 1,7 \%$, le groupe IV : $9,7 \pm 1,8 \%$, le groupe $V$ : $9,2 \pm 1,9 \%$.

Conclusion : Cette étude suggère que le propofol peut prévenir la mort neuronale tardive dans le sous-champ CAl hippocampique à la suite d'une ischémie/reperfusion chez les gerbilles.

From the Department of Anesthesiology, Dokkyo University School of Medicine, Mibu, Tochigi 321-0293, Japan. Address correspondence to: Shigeki Yamaguchi MD. Phone: 81-282-861111, Ext. 3802; Fax: 81-282-860478 Accepted for publication March 13, 1999 
$\mathrm{P}$ ROPOFOL, 2,6-diisopropylphenol, has cerebral vascular and metabolic effects similar to barbiturates. ${ }^{1}$ It is used for maintenance of neurosurgical anesthesia because it reduces the cerebral metabolic rate, ${ }^{2-4}$ cerebral blood flow, 5,6 and intracranial pressure. ${ }^{1,7}$ However, consensus has not been reached as to a protective effect of propofol on cerebral ischemia. Both positive ${ }^{8}$ and negative $^{9-12}$ results have been reported with different experimental materials and different methods of ischemia. Most negative results were obtained from extended cerebral ischemia. In this study, we examined the cerebral protective effect of propofol on delayed neuronal death after a short period of ischemia/reperfusion in gerbils.

\section{Methods}

This study was conducted according to the animal experimentation guidelines of Dokkyo University School of Medicine, which adhere to the National Institute of Health Animal Experimental Guidelines.

\section{Experimental protocol}

Thirty-five Mongolian gerbils weighing between 75 $95 \mathrm{~g}$ were divided into the following five groups.

Group I: $15 \mathrm{ml} \cdot \mathrm{kg}^{-1}$ physiological saline solution (PSS) were administered intraperitoneally $30 \mathrm{~min}$ before a sham operation $(n=7)$.

Group II: $15 \mathrm{ml} \cdot \mathrm{kg}^{-1}$ PSS were administered intraperitoneally $30 \mathrm{~min}$ before ischemia/reperfusion $(\mathrm{n}=7)$.

Group III: $50 \mathrm{mg} \cdot \mathrm{kg}^{-1}$ propofol with $10 \mathrm{ml} \cdot \mathrm{kg}^{-1}$ PSS were administered intraperitoneally $30 \mathrm{~min}$ before ischemia/reperfusion $(\mathbf{n}=7)$.

Group IV: $100 \mathrm{mg} \cdot \mathrm{kg}^{-1}$ propofol with $5 \mathrm{ml} \cdot \mathrm{kg}^{-1}$ PSS were administered intraperitoneally $30 \mathrm{~min}$ before ischemia/reperfusion $(n=7)$.

Group V: $150 \mathrm{mg} \cdot \mathrm{kg}^{-1}$ propofol were administered intraperitoneally $30 \mathrm{~min}$ before ischemia/reperfusion $(\mathrm{n}=7)$.

The sedation level was recorded five minutes after administration of PSS or propofol using the grade of sedation reported by Lowson et al. ${ }^{13}$ (Table I).

Then, a rubber bag was placed over the head of each gerbil and nitrous oxide $50 \%$ in oxygen with halothane (end-tidal concentration: 1.0-1.5\%) was administered throughout the procedure. The animals were placed in the supine position and the common carotid arteries were exposed bilaterally. In the control group, no further procedures were performed. In groups II through V, the common carotid arteries were occluded with miniature aneurysmal clips for four minutes. During this period we verified the
TABLE I Grades of sedation

grade 1: Mongolian gerbils active and grooming with normal exploratory activity. No apparent sedation.

grade 2: Decreased coordination with dragging of hind quarters, still active.

grade 3: Staggering with inability to walk along the edge of a tray. Easier to handle.

grade 4: Severe loss of coordination, with tendency to slither on the stomach rather than walk.

grade 5: Mongolian gerbils unable to walk and slithering.

grade 6: Lying immobile, righting reflex lost. Response to tail pinch reduced but present in gerbil.

grade 7: Righting reflex lost. Response to tail pinch was also markedly reduced or lost in gerbil.

TABLE II Cell degenerative ratio

\begin{tabular}{lll}
\hline Group & & $\begin{array}{l}\text { Degeneratipe ratio } \\
(\text { mean } \pm S D)\end{array}$ \\
\hline I & $\begin{array}{l}\text { Sham operation, saline-treated } \\
\text { II }\end{array}$ & $\begin{array}{l}\text { Ischemia-reperfusion, saline-treated } \\
9.9 .6 \pm 2.9 \%\end{array}$ \\
III & $\begin{array}{l}\text { Ischemia-reperfusion, propofol } \\
\left(50 \mathrm{mg} \cdot \mathrm{kg}^{-1}\right) \text {-treated }\end{array}$ & $10.7 \pm 1.7 \%$ \\
IV & $\begin{array}{l}\text { Ischemia-reperfusion, propofol } \\
\left(100 \mathrm{mg} \cdot \mathrm{kg}^{-1}\right) \text {-treated }\end{array}$ & $9.7 \pm 1.8 \%$ \\
V & $\begin{array}{l}\text { Ischemia-reperfusion, propofol } \\
\left(150 \mathrm{mg} \cdot \mathrm{kg}^{-1}\right) \text {-treated }\end{array}$ & $9.2 \pm 1.9 \%$ \\
\hline
\end{tabular}

* $P<0.01$ ps other groups I, III, IV, V. Values are mean \pm SD. Degenerative ratio $(\%)=$ number of degenerative pyramidal cells)/(total number of pyramidal cells per $1 \mathrm{~mm}$ hippocampal CAl subfield) $\times 100$.

absence of blood supply from the vertebral arteries with a microscope. Four minutes after occluding the bilateral carotid arteries, the clips were released and we visually confirmed spontaneous circulatory reperfusion with the microscope. The temperature of the tympanic membrane was monitored (Mon-a-therm Model 6510; Mallinckrodt) and maintained with a heating blanket at $37 \pm 0.2^{\circ} \mathrm{C}$ during the experiment.

Respiration of the animals, by visual inspection, was temporarily shallow during the procedure but this improved after reperfusion. The animals were kept and fed in the cage at a room temperature of $26^{\circ} \mathrm{C}$. Five days later, laparotomy and thoracotomy were performed on all gerbils under halothane anesthesia. Fixation was achieved by irrigation with a fixative solution (1:2:7 ratio of 4\% formaldehyde : phosphate buffer solution : distilled water) via the heart. The bodies were stored in a refrigerator at $4^{\circ} \mathrm{C}$ for two hours. A craniotomy was performed and the cerebrum was extracted and embedded in paraffin which was sliced into $5 \mu \mathrm{m}$ sections in the coronal direction and stained with hema- 


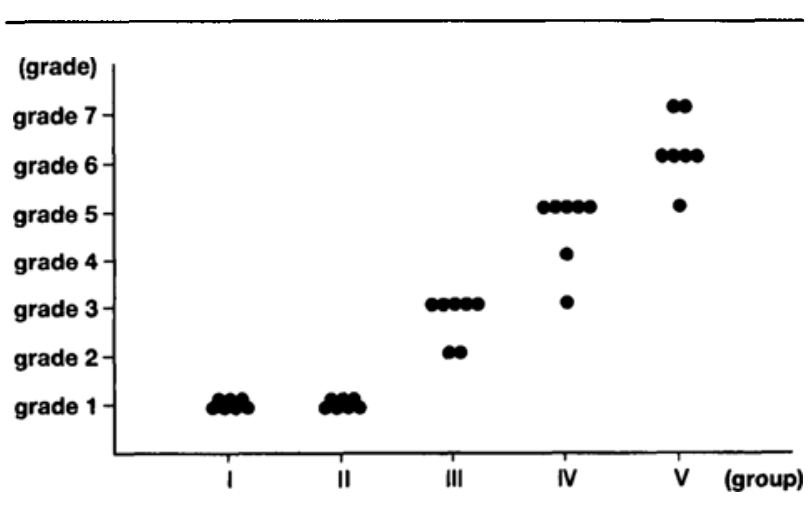

FIGURE 1 The grade of sedation was recorded five minutes after administration of PSS or propofol. Each closed circle represents a gerbil. All gerbils that received propofol were apparently sedated. Incremental doses of propofol produced mild sedation to deep anesthesia.

toxylin and cosin. Histopathological changes in the hippocampal CAl subfield were examined using a light microscope (Olympus BH-2, Olympus, Japan). Morphological changes were detected in the pyramidal cells and structural changes in the cell layers of the CAl subfield of the hippocampus. In order to compare the ratios of degenerative pyramidal cells among the five groups, the total number and the degenerative number of pyramidal cells were counted over a uniform $1 \mathrm{~mm}$ length of the central area of the hippocampal CAl subfield. The degenerative ratios were determined according to the following formula: Degenerative ratio $(\%)=$ (number of degenerative pyramidal cells/total number of pyramidal cells per $1 \mathrm{~mm}$ of hippocampal CAl subfield) $\times 100$.

Signs of degenerative processes such as atrophy of the pyramidal cells, deep staining of their cell bodies, vacuolation, and disappearance of the radial striated zone were taken to indicate cell degeneration, and cells in which these signs were absent were regarded as normal neurons. ${ }^{14,15}$

\section{Statistical analysis}

Data are presented as mean \pm SD. Kruskall-Wallis oneway analysis of variance was used for the statistical comparisons between each group. Statistical significance was considered to be $P<0.05$.

\section{Results}

Sedation

The grades of sedation for each group are shown in Figure 1. In groups I and II, no gerbil showed any sedation after administration of PSS. All gerbils which received propofol were sedated. Incremental doses of propofol produced mild sedation to deep anesthesia.

\section{Histopathological findings}

The histological appearances from each group are shown in Figure 2. In group I, normal pyramidal cells were well preserved and no disruption of the radial striated zone was detected. In group II, almost all the pyramidal cells were atrophic and pycnotic and exhibited deep staining of the cell cytoplasm, vacuolation, as well as structural disruption of the radial striated zone due to degenerative necrosis. In groups III, IV and $\mathrm{V}$, the pyramidal cells of the hippocampal CAl subfield were maintained as morphologically normal structures and no structural disruption was observed in the radial striated zones.

\section{Degenerative ratios}

The degenerative ratio in group I was $5.9 \pm 1.9 \%$ and was the lowest among all groups. In group II, it was $94.6 \pm 2.5 \%(P<0.01$ vs group I). The degenerative ratios in groups III, IV and V were lower than those in group II $(P<0.01)$ (Table II).The administration of propofol before ischemia/reperfusion produced an inhibitory action on delayed neuronal death. In this study the cerebral protective effects of propofol were not dose-dependent.

\section{Discussion}

The pyramidal cells of the hippocampal CAl are known for their selective vulnerability, similar to the Purkinje's cells and the third and fifth layers of the neocortex. ${ }^{16}$ The hippocampal CAl of the Mongolian gerbil (Meriones unguiculatus) has, in particular, been used as a model for cerebral ischemia and infarction..$^{15}$ Since the gerbil lacks an interconnection between the carotid and vertebrobasilar circulation, cerebral ischemia is easily produced by occlusion of the common carotid arteries. The neuronal damage in hippocampal CAI of the gerbil was similar to that observed in humans ${ }^{17,18}$ and other experimental animals. ${ }^{19}$ Kirino $^{15}$ showed that the pyramidal cells were gradually damaged to the point of delayed neuronal death after a short period of ischemia/reperfusion in gerbils. There was no histopathological change in the pyramidal cells on the first or second day after cerebral ischemia/reperfusion, and they became degenerative on the third or fourth day. In the recent studies, the mechanisms of the delayed neuronal death after transient ischemia have been considered as apoptosis or programmed cell death..$^{20-23}$ However, the delayed neuronal death has been still unclear and a consensus has not been reached. In this study, we examined the protective effects 


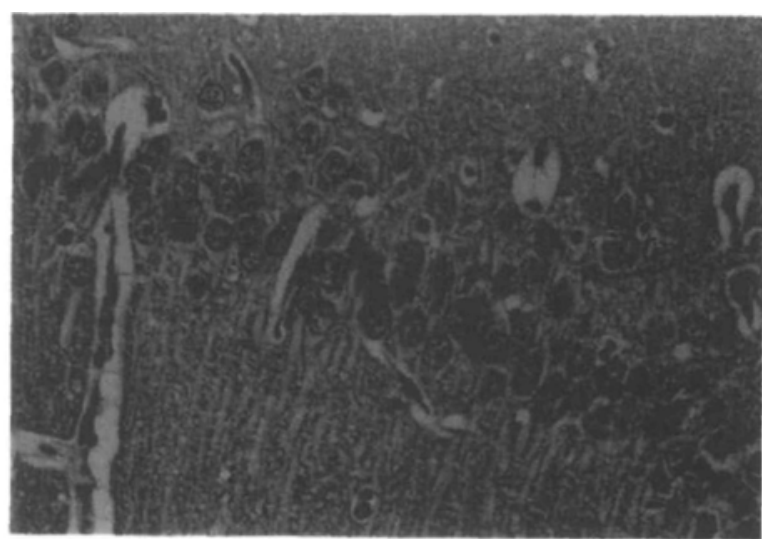

A

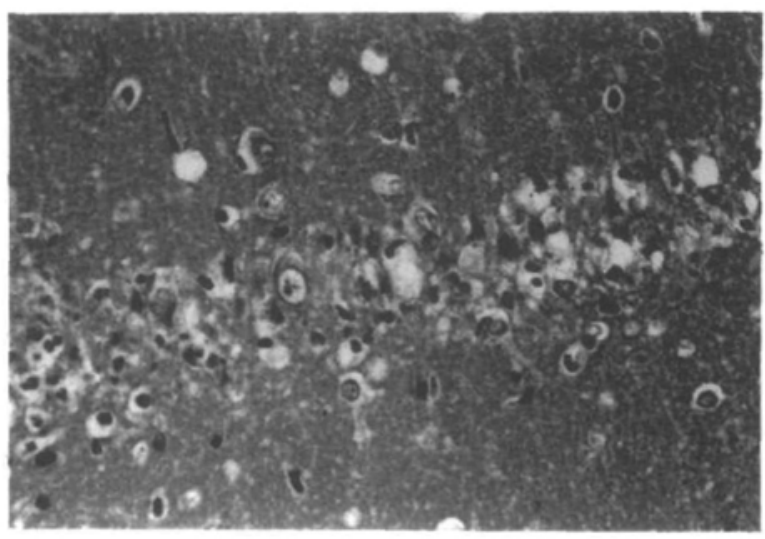

B

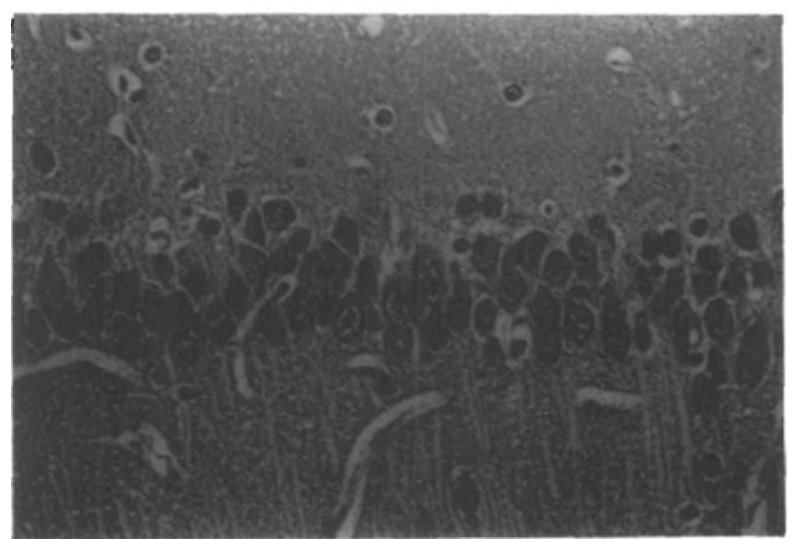

C

of propofol on delayed neuronal death after a short period of ischemia/reperfusion in gerbils. Pre-administration of propofol during $\mathrm{N}_{2} \mathrm{O} / \mathrm{O}_{2} /$ halothane anesthesia attenuated histopathological changes on the fifth day after the ischemia/reperfusion. Since $\mathrm{N}_{2} \mathrm{O} / \mathrm{O}_{2} /$ halothane anesthesia without propofol does not prevent delayed neuronal death, propofol may have a cerebral protective effects on delayed neuronal death after a short period of

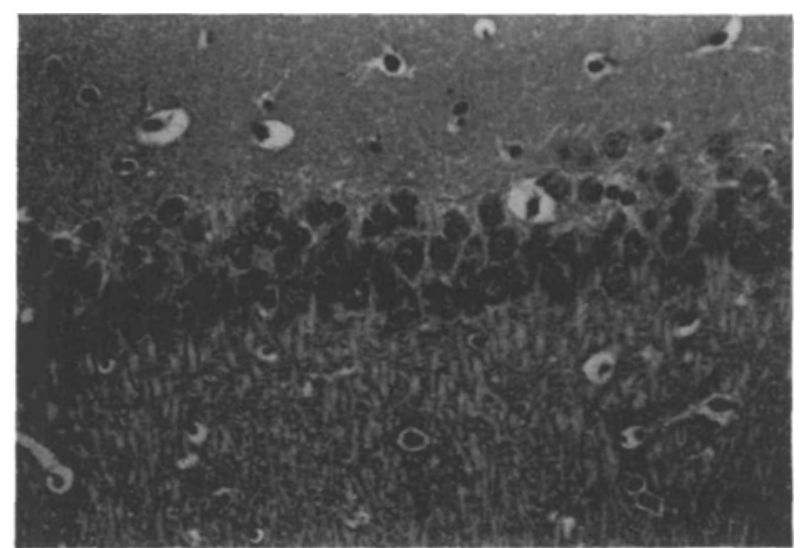

$\mathrm{D}$

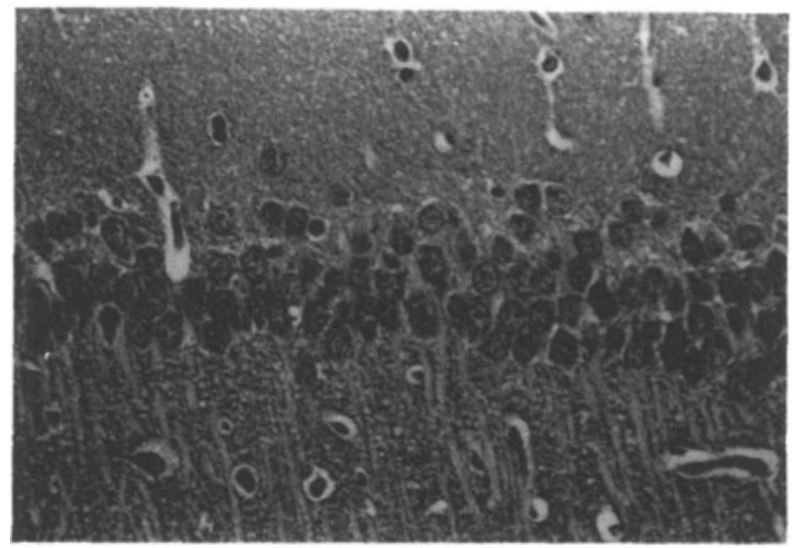

$\overrightarrow{\mathrm{E}}$

FIGURE 2 (a) - (c)

The histological appearances of hippocampal CAI from each group. (a) Group I; the normal structure of the CAl pyramidal cells is well preserved. (b) Group II; changes of the CAl pyramidal cells are present: cell shrinkage, nuclear pycnosis, dark cytoplasmic coloration and vacuolation. In (c-e) Groups III- V, the normal structure of the CAl pyramidal cells is preserved.

ischemia/reperfusion.

Delayed neuronal death may be due to an abnormal release of glutamate as an excitatory neurotransmitter, ${ }^{24,25}$ an increase of intracellular $\mathrm{Ca}^{2+},{ }^{26,27}$ followed by cellular death. In addition, since $\mathrm{N}$-methyl-D-aspartate (NMDA) receptors, a type of glutamate receptor, are concentrated in the hippocampal $\mathrm{CAl},{ }^{28}$ greater glutamate excitotoxicity affects delayed neuronal death. Hans 
et al..$^{29}$ showed that propofol attenuated the neurotoxicity of NMDA receptor-mediated glutamate using cultured hippocampal neurons. They also reported that propofol acted as a noncompetitive antagonist of NMDA receptors because of the presence of a phenylcycle, which was also contained by MK801 and ketamine, noncompetitive antagonists of the NMDA receptors. Propofol also prevents the neurotoxic vacuole reaction induced by $M K 801 .^{30}$ Orser $e t a l .^{31}$ found that propofol inhibited the NMDA subtype of glutamate receptors, possibly through an allosteric modulation of channel gating rather than by blocking the open channel. Bianchi et al..$^{32}$ showed that propofol slightly inhibited the release of glutamate and glutamate dependent $\mathrm{Ca}^{2+}$ entry because it depressed the voltage-gated calcium channels using rat synaptosomes. However, Zhu et al ${ }^{30}$ demonstrated that propofol enhanced NMDA-induced neuronal damage using the recovery of the population spike amplitude as an indicator of neuronal viability. Amorim $e t a l^{33}$ reported that propofol attenuated the increase of intracellular $\mathrm{Ca}^{2+}$ but does not depress the release of glutamate using hippocampal slices. ${ }^{11}$ Although the mechanism of cerebral protective effects of propofol $v s$ cerebral ischemia is not well understood, it may be due to the inhibition of increase of intracellular $\mathrm{Ca}^{2+}$, which is provoked by glutamate. ${ }^{29,32}$

Different methods have been used to determine the amount of brain damage after transient ischemia. ${ }^{14,34-36}$ These include a volume estimate of the infarcted zone using measurements of infarcted surface area $^{34}$ and stereological methods. ${ }^{35}$ Another is the count of degenerative neurons. ${ }^{14,36}$ In the present study, we used the latter method because it was easy to estimate the neuronal damage of a local area such as pyramidal cells in the hippocampal CAl.

We administered 50,100 and $150 \mathrm{mg} \cdot \mathrm{kg}^{-1}$ propofol intraperitoneally $\mathbf{3 0} \mathrm{min}$ before inducing ischemia. Each dose of propofol protected the pyramidal cells of hippocampal CAI from degeneration, followed by delayed neuronal death. Lowson et al. ${ }^{13}$ showed that 50, 100 and $150 \mathrm{mg} \cdot \mathrm{kg}^{-1}$ propofol administered intraperitoneally, caused sedation, light and deep anesthesia, respectively. We also confirmed this in the present study.

We conclude that the administration of propofol may prevent delayed neuronal death after a short period of cerebral ischemia/reperfusion, and that small doses of propofol may depress delayed neuronal death.

\section{Acknowledgments}

We thank H. Sakurai and F.S. Davidson for their assistance in editing the English text of this paper.

\section{References}

1 Pinaud $M$, Lelausque J-N, Chetanneau $A$, Fauchoux $N$, Ménégalli $D$, Souron $R$. Effects of propofol on cerebral hemodynamics and metabolism in patients with brain trauma. Anesthesiology 1990; 73: 404-9.

2 Sebel PS, Lowdon JD. Propofol: a new intravenous anesthetic. Anesthesiology 1989; 71: 260-77.

3 Van Hemelrijck J, Fitch W, Mattheussen M, Van Aken $H$, Plets $C$, Lauwers $T$. Effect of propofol on cerebral circulation and autoregulation in the baboon. Anesth Analg 1990; 71: 49-54.

4 Vandesteene A, Trempont V, Engelman E, et al. Effect of propofol on cerebral blood flow and metabolism in man. Anaesthesia 1988; 43(Suppl): 42-3.

5 Dam $M$, Ori $C$, Pizzolato $G$, et al. The effects of propofol anesthesia on local cerebral glucose utilization in the rat. Anesthesiology 1990; 73: 499-505.

6 Stephan $H$, Sonntag $H$, Schenk $H D$, Koblhausen S. Effects of disoprivan on cerebral blood flow, cerebral oxygen consumption, and cerebral vascular reactivity. (German) Anaesthesist 1987; 36: 60-5.

7 Ravussin P, Guinard JP, Ralley $F$, Thorin D. Effect of propofol on cerebrospinal fluid pressure and cerebral perfusion pressure in patients undergoing craniotomy. Anaesthesia 1988; 43(Suppl): 37-41.

8 Kochs E, Hoffinan WE, Werner C, Thomas C, Albrecht $R F$, am Esch JS. The effects of propofol on brain electrical activity, neurologic outcome, and neuronal damage following incomplete ischemia in rats.

Anesthesiology 1992: 76: 245-52.

9 Ridenour TR, Warner DS, Todd MM, Gionet TX. Comparative effects of propofol and halothane on outcome from temporary middle cerebral artery occlusion in the rat. Anesthesiology 1992; 76: 807-12.

10 Weir DL, Goodchild CS, Grabam DI. Propofol: effects on indices of cerebral ischemia. J Neurosurg Anesth 1989; 1: 284-9.

11 Illievich UM, Zornow $M H$, Choi KT, Strnat MAP, Scheller MS. Effects of hypothermia or anesthetics on hippocampal glutamate and glycine concentrations after repeated transient global cerebral ischemia. Anesthesiology 1994; 80: 177-86.

12 Arcadi $F A$, Rapisarda $A$, De Luca $R$, Trimarchi $G R$, Costa $G$. Effect of 2,6-diisopropylphenol on the delayed hippocampal cell loss following transient forebrain ischemia in the gerbil. Life Sci 1996; 58: 961-70.

13 Lowson S, Gent JP, Goodchild CS. Anticonvulsant properties of propofol and thiopentone: comparison using two tests in laboratory mice. Br J Anaesth 1990; 64: 59-63.

14 Hamaguchi $S$, Ogata $H$. Does hypertonic saline have preventive effects against delayed neuronal death in gerbil hippocampus? Shock 1995; 3: 280-3. 
15 Kirino $T$. Delayed neuronal death in the gerbil hippocampus following ischemia. Brain Res 1982; 239: 57-69.

16 Pulsinelli WA, Brierley JB, Plum F. Temporal profile of neuronal damage in a model of transient forebrain ischemia. Ann Neurol 1982; 11: 491-8.

17 Petito CK, Feldmann E, Pulsinelli WA, Plum F. Delayed hippocampal damage in humans following cardiorespiratory arrest. Neurology 1987; 37: 1281-6.

18 Horn $M$, Scblote $W$. Delayed neuronal death and delayed neuronal recovery in the human brain following global ischemia. Acta Neuropathol 1992; 85: 79-87.

19 Brown AW, Lepy DE, Kublik M, Harrow J, PlumF, Brierley $J B$. Selective chromatolysis of neurons in the gerbil brain: a possible consequence of "epileptic" activity produced by common carotid artery occlusion. Ann Neurol 1979; 5: 127-38.

20 Maeda $M$, Sugiyama $T$, Akai F, Jikibara I, Hayashi $\Upsilon$, Takagi $H$. Single stranded DNA as an immunocytochemical marker for apoptotic change of ischemia in the gerbil hippocampus. Neurosci Lett 1998; 240: 69-72.

21 Kinoshita M, Tomohito H, Kinosita A, Kumar S, Noda $M$. Up-regulation of the Nedd2 gene encoding an ICE/Ced-3-like cysteine protease in the gerbil brain after transient global ischemia. J Cereb Blood Flow Metab 1997; 17: 507-14.

22 Nitatori $T$, Sato $N$, Waguri S, et al. Delayed neuronal death in the CAl pyramidal cell layer of the gerbil hippocampus following transient ischemia is apoptosis. J Neurosci 1995; 15: 1001-11.

23 Kibara S, Shiraishi T, Nakagawa S, Toda K, Tabuchi K. Visualization of DNA double strand breaks in the gerbil hippocampal CAl following transient ischemia. Neurosci Lett 1994; 175: 133-6.

24 Benvensite H, Drejer J, Schousboe A, Diemer NH. Elevation of the extracellular concentrations of glutamate and aspartate in rat hippocampus during transient cerebral ischemia monitored by intracerebral microdialysis. J Neurochem 1984; 43: 1369-74.

25 Rothman SM, Olney JW. Glutamate and the pathophysiolgy of hypoxic-ischemic brain damage. Ann Neurol 1986; 19: 105-11.

26 Sakamoto N, Kogure K, Kato H, Obtomo $H$. Disturbed $\mathrm{Ca}^{2+}$ homeostasis in the gerbil hippocampus following brief transient ischemia. Brain Res 1986; 364: 372-6.

27 Deshpande JK, Siesjö BK, Wieloch T. Calcium accumulation and neuronal damage in the rat hippocampus following cerebral ischemia. J Cereb Blood Flow Metab 1987; 7: 89-95.

28 Monaghan DT, Holets VR, Toy DW, Cotman CW. Anatomical distributions of four pharmacologically distinct ${ }^{3} \mathrm{H}$-L-glutamate binding sites. Nature $1983 ; 306$ : 176-9.
29 Hans $P$, Bonbomme V, Collette J, Albert A, Moonen G. Propofol protects cultured rat hippocampal neurons against $\mathrm{N}$-methyl-D-aspartate receptor-mediated glutamate toxicity. J Neurosurg Anesth 1994; 6: 249-53.

30 Zhu H, Cottrell JE, Kass IS. The effect of thiopental and propofol on NMDA- and AMPA-mediated glutamate excitotoxicity. Anesthesiology 1997; 87: 944-51.

31 Orser BA, Bertlik M, Wang L-, , MacDonald JF. Inhibition by propofol (2,6 di-isopropylphenol) of the $\mathrm{N}$-methyl-D-aspartate subtype of glutamate receptor in cultured hippocampal neurones. $\mathrm{Br} \mathrm{J}$ Pharmacol 1995; 116: 1761-8.

32 Bianchi M, Battistin T, Galzigna L. 2, 6Diisopropylphenol, a general anesthetic, inhibits glutamate action on rat synaptosomes. Neurochem Res $1991 ; 16: 443-6$.

33 Amorim P, Chambers G, Cottrell J, Kass IS. Propofol reduces neuronal transmission damge and attenuates the changes in calcium, potassium, and sodium during hyperthermic anoxia in the rat hippocampal slice. Anesthesiology 1995; 83: 1254-65.

34 Memezawa $H$, Smith $M-L$, Siejö $B K$. Penumbral tissues salvaged by reperfusion following middle cerebral artery occlusion in rats. Stroke $1992 ; 23$ : 552-9.

35 Avendaño C, Roda JM, Carceller F, Díez-Tejedor $E$. Morphometric study of forcal cerebral ischemia in rats: a stereological evaluation. Brain Res 1995; 673: 83-92.

36 Tamaguchi S, Ogata H, Hamaguchi S, Kitajima T. Superoxide radical generation and histopathological changes in hippocampal CAI after ischemia/reperfusion in gerbils. Can J Anaesth 1998; 45: 226-32. 